AL-URBAN: Jurnal Ekonomi Syariah dan Filantropi Islam

Vol. 2, No. 2, Desember 2018

http://journal.uhamka.ac.id/index.php/al-urban

p-ISSN: 2580-3360 e-ISSN: 2581-2874

DOI: $10.22236 /$ alurban_vol2/is2pp135-145

Hal 135-145

\title{
PERSEPSI MASYARAKAT TENTANG HUKUM SYARIAH MENABUNG DI BANK DAN TINGKAT LITERASI KEUANGAN SYARIAH
}

\author{
Atep Hendang Waluya ${ }^{1}$, Samsuri ${ }^{2}$
}

${ }^{12}$ Universitas Muhammadiyah Tangerang

Email: atepwaluya@umt.ac.id ${ }^{1}$, Syamsurisane2013@gmail.com²

Diterima: 3 November 2018; Direvisi: 7 November 2018; Disetujui: 20 Desember 2018

\begin{abstract}
This study has three objectives. First, to find out the people of Tangerang City perception about sharia law regarding saving in Islamic and conventional banks. Second, to find out their Islamic financial literacy level. And third, to determine the relationship between their perceptions and their Islamic financial literacy level. This study uses quantitative methods with primary data collected by integrating questionnaires in 13 sub-districts in the city of Tangerang. The method used to determine the number of samples is the Slovin formula, while data analysis uses the Kendall's Tau correlation. This study produced several findings. First, the perception of the Tangerang city people about the law of saving in Islamic banks is dominated by the answer recommended, while the saving law in conventional banks according to the majority of the people of Tangerang City is permissible. Second, the level of sharia financial literacy in Tangerang City is low, with the lowest indicators are their skills in using Islamic financial services. Third, there is a strong relationship between the people of Tangerang City perception about sharia law saving in banks with the level of Islamic financial literacy.
\end{abstract}

Keywords: Perception, Islamic Financial Literacy, Saving, Tangerang

Abstrak

Penelitian ini memiliki tiga tujuan. Pertama, untuk mengetahui persepsi masyarakat Kota Tangerang tentang hukum syariah menabung di bank. Kedua, mengetahui tingkat literasi keuangan syariah. Ketiga, mengetahui hubungan antara persepsi mereka dengan tingkat literasi keuangan syariah. Metode yang digunakan adalah metode kuantitatif. Teknik pengumpulan data primer dilakukan dengan menyebarkan kuisioner di 13 Kecamatan yang ada di kota Tangerang. Metode yang digunakan untuk menentukan jumlah sampel menggunakan rumus Slovin. Analisis data korelasi menggunakan Korelasi Kendall Tau.Hasil dari penelitian ini menunjukkan bahwa persepsi masyarakat kota Tangerang tentang hukum menabung di bank syariah didominasi dengan dianjurkan. Adapun tentang hukum menabung di bank konvensional kebanyakan masyarakat kota Tangerang menjawab bahwa menabung di bank konvensional adalah boleh. Tingkat literasi keuangan syariah mayarakat kota Tangerang masih rendah, indikator yang paling terendah adalah keterampilan mereka dalam menggunakan jasa keuangan syariah. Terdapat hubungan yang kuat antara persepsi masyarakat kota Tangerang tentang hukum syariah menabung di bank dengan tingkat literasi keuangan syariah.

Kata Kunci: Persepsi, Literasi Keuangan Syariah, Menabung, Tangerang 
Atep Hendang Waluya $\mathbf{1 3 6}$

\section{PENDAHULUAN}

Melihat kepada sejarah bahwa perkembangan bank syariah di Indonesia sudah mencapai kurang lebih 3 windu. Pada awal permulaan berdirinya bank syariah, landasan hukum yang dijadikan landasan operasionalnya adalah UU no 7 Tahun 1992, pada pasal 6 poin I disebutkan bahwa bank umum dalam usahanya menyediakan pembiayaan bagi nasabah berdasarkan prinsip bagi hasil sesuai dengan ketentuan yang ditetapkan dalam Peraturan Pemerintah. Dalam PP no 72 tahun 1992 disebutkan bahwa yang dimaksud bagi hasil adalah prinsip bagi hasil berdasarkan syari'at. Dalam PP tersebut juga disebutkan bahwa bank berdasarkan prinsip bagi hasil wajib memiliki Dewan Pengawas Syari'at. Pada tahun 1998, UU no 7 Tahun 1992 diamandemen dengan UU no 10 tahun 1998, dalam UU tersebut belum secara spesifik membahas bank syariah. Bank Syariah di Indonesia baru memiliki payung hukum yang kuat dan jelas setelah terbitnya UU no 21 tahun 2008. Pada UU inilah secara tegas nama Bank Syariah disebutkan.

Menurut Prasetiyo (2012) setelah UU perbankan syariah tahun 2008 disahkan bank syariah di Indonesia terus berkembang. Namun di sisi lain sebagaimana disebutkan dalam siaran pers OJK (2018) bahwa market share industri keuangan syariah di Indonesia baru 8,01 persen jika dibandingkan dengan total aset industri keuangan konvensional.

Berdasarkan data BPS (2010) bahwa Provinsi Banten menduduki peringkat ke empat jumlah muslim terbanyak di Indonesia, yaitu mencapai 10.065.783 jiwa, jumlahpendudukBantensemuanya(muslim dan non muslim) adalah 10.632.168 jiwa. Besarnya populasi masyarakat muslim di Banten merupakan modal besar untuk meningkatkan perkembangan bank syariah di Provinsi Banten pada khususnya dan merupakan pangsa pasar yang potensial untuk perkembangan perbankan syariah secara nasional umumnya ke depan.

Provinsi Banten terdiri dari 4 kota dan 4 kabupaten. Penduduk muslim di Kota Tangerang merupakan penduduk muslim terbanyak ke dua di provinsi Banten setelah Kabupaten Tangerang. Populasi penduduk di Kota Tangerang mencapai 1 798601 jiwa, penduduk muslimnya adalah 1587272 jiwa. Meskipun mayoritas penduduk Banten adalah muslim, namun perkembangan bank syariah di Provinsi Banten kurang begitu menggembirakan. Menurut data statistik OJK bulan Desember 2016, bahwa Dana Pihak Ketiga (DPK) baik Bank Umum Syariah (BUS) maupun Unit Usaha Syariah (UUS) adalah 6.751 M. Dengan rincian DPK BUS adalah $5.805 \mathrm{M}$ sedangkan UUS adalah $946 \mathrm{M}$.

Dana DPK bank syari'ah di Banten jauh sekali dibandingkan dana DPK Bank Konvensional di Banten yang mencapai 149.874 $\mathrm{M}$ atau sekitar $2.99 \%$ dari total DPK Bank Konvensinal se Indonesia. Sedangkan untuk DPK BPR di Banten sekitar $1.641 \mathrm{M}$ atau sekitar 2.17 dari total DPK BPR se-Indonesia. 
Tabel 1.1

Perbandingan DPK Bank Syariah dan Bank Konvensional di Banten Tahun 2016

\begin{tabular}{|c|c|}
\hline BANK & DPK \\
\hline Bank Syariah & 6.751 \\
\hline Bank Konvensional & 149.874 \\
\hline BPRS & 1.641 \\
\hline BPR & $\mathbf{6 2 7 . 9 7 3}$ \\
\hline
\end{tabular}

Sumber: SPI dan SPS 2016 OJK, data diolah oleh penulis

ahun 2017 bahwa pada Desember 2016 perkembangan perbankan syariah di provinsi Banten dengan dana pihak ketiga (DPK) paling tertinggi adalah kota Tangerang dengan DPK $3.114 \mathrm{M}$ sedangkan yang paling rendah adalah kota Serang yang hanya mencapai $86 \mathrm{M}$.

Persepsi mayarakat kota Tangerang tentang hukum syariah menabung di bank yang dimaksud dalam penelitian ini adalah pandangan atau pengetahuan mereka tentang bagaimana hukum menabung di bank menurut hukum Islam. Wadiah al mashrifiyyah atau simpanan di bank menurut jumhur fukaha kontemporer sebagaimana dijelaskan oleh Waluya (2017) bahwa mereka memandangnya sebagai akad utang piutang. Oleh karena itu wadiah di bank dibangun atas dasar yad dhamanah, bukan yad amanah.

Muhammad bin Shalih Al Munajjid ketika ditanya bagaimana hukumnya membuka rekening di bank konvensional tanpa mengambil bunganya?. Ia menjawab bahwa fukaha sepakat tidak boleh membuka rekening di bank konvensional dan menyimpan uang padanya lalu mengambil bunganya. Adapun jika membuka rekening dan menabung di bank konvensional tanpa bertujuan mengambil dan memanfaatkan bunganya maka dalam hal ini para fukaha berbeda pendapat. Menurutnya pendapat yang paling hati-hati adalah tidak boleh menabung di bank konvensional meskipun tidak mempunyai niyat mengambil dan memanfaatkan bunganya, kecuali kalau dalam keadaaan darurat atau ada kebutuhan yang mengharuskan hal tersebut.

ahun 2017 bahwa pada Desember 2016 perkembangan perbankan syariah di provinsi Banten dengan dana pihak ketiga (DPK) paling tertinggi adalah kota Tangerang dengan DPK $3.114 \mathrm{M}$ sedangkan yang paling rendah adalah kota Serang yang hanya mencapai $86 \mathrm{M}$.

Persepsi mayarakat kota Tangerang tentang hukum syariah menabung di bank yang dimaksud dalam penelitian ini adalah pandangan atau pengetahuan mereka tentang bagaimana hukum menabung di bank menurut hukum Islam. Wadiah al mashrifiyyah atau simpanan di bank menurut jumhur fukaha kontemporer sebagaimana dijelaskan oleh Waluya (2017) bahwa mereka memandangnya sebagai akad utang piutang. Oleh karena itu wadiah di bank dibangun atas dasar yad dhamanah, bukan yad amanah.

Muhammad bin Shalih Al Munajjid ketika ditanya bagaimana hukumnya membuka rekening di bank konvensional tanpa mengambil bunganya?. Ia menjawab bahwa fukaha sepakat tidak boleh membuka rekening di bank konvensional 
Atep Hendang Waluya 138

dan menyimpan uang padanya lalu Menurut Penelitian Rakhmah (2015) mengambil bunganya. Adapun jika bahwa variabel persepsi mahasiswa membuka rekening dan menabung di bank tentang Bank Syariah memiliki pengaruh konvensional tanpa bertujuan mengambil dan memanfaatkan bunganya maka dalam hal ini para fukaha berbeda pendapat. yang signifikan terhadap minat menabung di Perbankan Syariah. Menurutnya pendapat yang paling hatihati adalah tidak boleh menabung di bank konvensional meskipun tidak mempunyai niyat mengambil dan memanfaatkan bunganya, kecuali kalau dalam keadaaan darurat atau ada kebutuhan yang mengharuskan hal tersebut.

Secara spesifik, menurut data statististik perbankan syariah yang dirilis oleh OJK pada tMenabung di bank konvensional meskipun tidak bertujuan mengambil bunga, hanya sekedar menabung saja menurut Al Musyaiqih, Affanah, Majma Al Fiqh Al Islami, Laznah Al Dzaimah Arab Saudi, Abdullah bin Baz dan Al Utsaimin adalah tidak boleh. Sedangkan menurut Al Dubyan dan Al Utsmani adalah makruh dan sebagian kecil fukaha membolehkan. (Waluya, 2017).

Islam Web lembaga fatwa yang menginduk kepada Kementrian Urusan Agama Qatar dalam fatwanya no 72308 mengatakan bahwa tidak boleh menabung dibank konvensional kecuali kalau darurat seperti karena tidak ada bank syariah di daerahnya atau karena ada kebutuhan seperti tidak bisa melakukan transaksi atau menerima transaksi kecuali dengan bank konvensional, maka dalam hal ini dibolehkan namun hanya sebatas transaksi harian saja.
Begitujuga Menurut Utami (2017) bahwa persepsi masyarakat tentang perbankan syariah memiliki pengaruh yang positif dan signifikan terhadap minat menabung di bank syariah.

Menurut penelitian Rahmawaty (2014) bahwa persepsi tentang bunga bank berpengaruh secara positif dan signifikan terhadap minat menggunakan produk bank syariah; dan persepsi tentang sistem bagi hasil berpengaruh secara positif dan signifikan terhadap minat menggunakan produk bank syariah.

Menurut Khosasi (2018) terdapat pengaruh literasi keuangan syariah terhadap pengambilan keputusan nasabah melakukan pembiayaan mikro di bank syariah Bukopin Sidoarjo.

Menurut Herdianti dan Utama (2018) bahwa variabel pengetahuan keuangan dasar syariah, tabungan syariah, invstasi syariah, asuransi syariah, pengetahuan lembaga keuangan syariah dan pengetahuan produk lembaga keuangan syariah berpengaruh signifikan terhadap minat mahasiswa non ekonomi menjadi nasabah lembaga keuangan syariah. Tingkat literasi keuangan syariah pada mahasiswa program studi non ekonomi UMY berada pada kategori sedang.

Menurut Mendari dan Soejono (2018) bahwa tingkat literasi keuangan 
139 AL-URBAN: Jurnal Ekonomi Syariah dan Filantropi Islam

Vol. 2, No. 2, Desember 2018

http://journal.uhamka.ac.id/index.php/al-urban

p-ISSN: 2580-3360 e-ISSN: 2581-2874

DOI: $10.22236 /$ alurban_vol2/is2pp135-145

Hal 135-145

dosen-dosen di Palembang sebesar

57,46 termasuk kategori rendah dengan

klasifikasi Basic Financial Literacy Index sebesar 68,45 termasuk dalam kategori moderat, dan Advanced Financial Literacy Index sebesar 46,47 termasuk dalam kategori rendah. Basic Financial Literacy Index untuk kategori moderat dan tinggi lebih dominan laki-laki dibandingkan perempuan, sebaliknya untuk kategori rendah perempuan lebih dominan dari laki-laki. Demikian juga untuk Advanced Financial Literacy Index laki-laki lebih dominan pada kategori moderat dan tinggi, sedangkan perempuan lebih dominan pada kategori rendah. Basic Financial Literacy Index berdasarkan golongan usia yang masuk dalam kategori tinggi dominan disetiap golongan usia sedangkan kategori rendah dan moderat cenderung memiliki proporsi yang seimbang. Sebaliknya untuk Advanced Financial Literacy Index dominan di kategori rendah mencapai diatas $70 \%$, kurang dari $10 \%$ yang masuk kategori tinggi.

Menurut OJK bahwa literasi Keuangan memiliki tujuan jangka panjang bagi seluruh golongan masyarakat, yaitu: (a) Meningkatkan literasi seseorang yang sebelumnya less literate atau not literate menjadi well literate; dan (b) Meningkatkan jumlah pengguna produk dan layanan jasa keuangan. Agar masyarakat luas dapat menentukan produk dan layanan jasa

keuangan yang sesuai dengan kebutuhan, masyarakat harus memahami dengan benar manfaat dan risiko, mengetahui hak dan kewajiban serta meyakini bahwa produk dan layanan jasa keuangan yang dipilih dapat meningkatkan kesejahteraan masyarakat.

Berdasarkan hal tersebut, pengetahuan masyarakat tentang haramnya menabung di bank konvensional akan meningkatkan literasi masyarakat tersebut untuk beralih menggunakan produk perbankan yang halal dalam hal ini ada dalam produk-produk perbankan syariah.

Survei Nasional Literasi dan Inklusi Keuangan (SNLIK) kedua sebagaimana yang dirilis di laman OJK pada tahun 2016 menunjukkan indeks literasi keuangan sebesar 29,66\% dan indeks inklusi keuangan sebesar $67,82 \%$. Kegiatan edukasi keuangan sejak tahun 2013 sampai dengan 2016 telah dilaksanakan di 144 kota dengan frekuensi sebanyak 289 kegiatan. Selain itu juga dalam rangka meningkatkan literasi keuangan di kalangan pelajar dan mahasiswa, OJK juga telah menyusun dan meluncurkan buku seri literasi keuangan untuk jenjang pendidikan formal mulai tingkat SD, SMP, SMA dan Perguruan Tinggi.

Adapun hasil survey mengenai tingkat literasi keuangan secara nasional sebagai berikut: 
Tabel 1

Hasil Survey OJK 2016 Tentang Tingkat Literasi Keuangan Secara Nasional

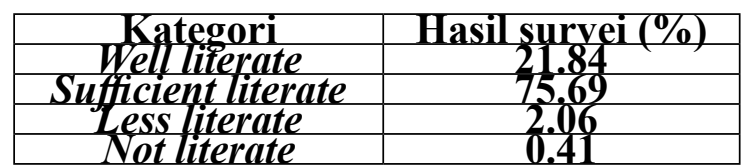

Sumber: Otoritas Jasa Keuangan 2016

Menurut Survei Nasional Literasi dan Inklusi Keuangan (SNLIK) yang dilakukan Otoritas Jasa Keuangan (OJK) pada tahun 2013 menunjukan bahwa rata-rata literasi keuangan masyarakat Indonesia berada pada kategori sufficient literate yaitu mencapai 75, 69 persen. Secara terperinci, indeks literasi perbankan meningkat dari 21,80 persen pada 2013 menjadi 28,94 persen pada 2016 .

Hal tersebut menjadi salah satu indikator bahwa dengan meningkatnya literasi keuangan syariah berhubungan dengan peningkatan kinerja lembaga perbankan syariah.

\section{METODE PENELITIAN}

Metode yang digunakan dalam penelitian ini adalah metode kuantitatif. Teknik pengumpulan data primer dilakukan dengan menyebarkan kuisioner kepada responden yang tersebar di 13 Kecamatan yang ada di
Kota Tangerang. Sedangkan data sekunder dikumpulkan melalui studi kepustakaan (library research) dengan mengadakan penelusuran terhadap dokumen-dokumen dari berbagai sumber yang relevan. Analisis data yang digunakan dalam penelitian ini adalah analisis kuantitatif deskriptif.

Metode yang digunakan untuk menentukan jumlah sampel adalah dengan menggunakan rumus Slovin (Sevilla: 2007), sebagai berikut:

$$
n=\frac{N}{1+N e^{2}}
$$

dimana

n: jumlah sampel

$\mathrm{N}$ : jumlah populasi

e: batas toleransi kesalahan (error tolerance)

\begin{abstract}
Populasi di kota Tangerang adalah sebanyak 1.798 .601 orang. Sampel penelitian dihitung berdasarkan rumus slovin sebagai berikut:
\end{abstract}

$$
\begin{gathered}
n=\frac{1.798 \cdot 601}{1+\mathbf{1 . 7 9 8 . 6 0 1}(0,10)^{2}} \\
n=99,99 \approx 100
\end{gathered}
$$

Berdasarkan rumus slovin di atas, wilayah kecamatan di masing-di kota sampel yang di kota Tangerang adalah Tangerang, yaitu dilakukan cluster sampel sebanyak 153 orang. Penarikan sampel di 13 Kecamatan di Kota Tangerang. dalam penelitian ini ditekankan kepada 
Tabel 2

Sampel Penelitian

\begin{tabular}{|c|c|c|c|}
\hline \multicolumn{4}{|c|}{ Kota Tangerang } \\
\hline Kecamatan & Jumlah Pendudük & Proporsi (\%) & Sampel \\
\hline Ciledug & 147.023 & 7.8 & 2 \\
\hline Larangan & 63,901 & & 2 \\
\hline Cipondoh & 216,346 & & \\
\hline Pinang & 160,206 & 8,5 & \\
\hline Tangeraing & 152,145 & 7,8 & \\
\hline Karawaci & $\frac{11}{20,316}$ & 7,28 & $\frac{14}{12}$ \\
\hline Cibodas & 142,479 & & 12 \\
\hline Periuk & 129,384 & 7,2 & 11 \\
\hline $\begin{array}{l}\text { Batuceper } \\
\text { Neglasari }\end{array}$ & $\begin{array}{l}90.590 \\
103.504\end{array}$ & 5,9 & 10 \\
\hline Benda & 83,017 & 5.9 & 9 \\
\hline JUMLAH & 1,798,601 & 100 & 153 \\
\hline
\end{tabular}

Sumber: BPS 2010, data diolah oleh penulis

Analisis data yang digunakan adalah analisis korelasi KendallTau. Menurut Sugiyono (2004) korelasi KendallTau digunakan untuk mencari hubungan dan menguji hipotesis antara dua variabel atau lebih, bila datanya berbentuk ordinal atau ranking.

\section{HASIL DAN PEMBAHASAN}

\section{Karakteristik Responden}

Responden dalam penelitian ini berjumlah 153 orang yang diambil dari 13 Kecamatan yangterdapat diKota Tangerang. Adapun rinciannya sebagai berikut 13 orang responden dari Kecamatan Pinang, 12 orang dari Kecamatan Jatiuwung, 11 orang dari Kecamatan Karang Tengah, 12 orang dari Kecamatan Tangerang, 14 orang dari Kecamatan Karawaci, 9 orang dari Kecamatan Benda, 10 orang dari Kecamatan Neglasari, 12 orang dari Kecamatan Ciledug, 9 orang dari Kecamatan Batu Ceper, 12 orang dari Kecamatan Cibodas, 11 orang dari Kecamatan Periuk, 16 orang dari Kecamatan Cipondoh, dan 12 orang dari Kecamatan Larangan.
Berdasarkan jenis kelamin, 84 orang atau 59,4 persen responden adalah lakilaki, sedangkan 66 orang atau 43,1 persen responden adalah perempuan.

Berdasarkan usia, 96 orang responden berusia antara 15-25 tahun, 39 responden berusia antara 26-35, dan 12 orang responden berusia antara 36-55 tahun.

Dari segi pendidikan akhir 3 orang atau 2 persen responden berpendidikan SD, 5 orang atau 3,3 persen responden berpendidikan SMP, 88 orang atau 57,5 persen responden berpendidikan SMA, 3 orang atau 2 persen responden berpendidikan MTs, 16 orang atau 10,5 responden berpendidikan MA, 10 orang atau 6,5 responden berpendidikan diploma, 17 orang atau 11,1 responden persen berpendidikan S1 umum, 8 orang atau 5,2 persen responden berpendidikan S1 keIslaman, 1 orang atau 0,7 persen responden berpendidikan S2 keIslaman.

Dari segi kependidikan agama Islam atau keislaman, 28 orang atau 18, 3 persen responden memiliki latar belakang pendidikan keagamaan/ keislaman. Sedangkan 125 orang atau 
Atep Hendang Waluya 142

81,7 persen responden tidak memiliki latar belakang pendidikan sekolah keagamaan.

Dari segi pekerjaan dapat diketahui bahwa 69 orang atau 41,5 persen responden bekerja sebagai karyawan swasta,41 orang atau 26,8 persen resonden adalah mahasiswa, 12 orang atau 7,8 persen responden bekerja wiraswasta, 10 orang atau 6,5 pesen responden bekerja sebagai guru, 8 orang atau 5,2 persen responden adalah pelajar, 8 orang atau 5,2 persen responden adalah PNS, 1 orang atau 0,7 persen responden adalah dosen.

Persepsi Masyarakat Kota Tangerang Tentang Hukum Syariah Menabung Di Bank

Berdasarkan hasil kuisioner yang dibagikan di 13 Kecamatan di Kota Tangerang tentang bagaimana hukum menabung di bank syariah dapat diketahui bahwa 63 orang atau 41,2 responden menjawab bahwa hukum menabung di bank syariah adalah boleh, 64 orang atau 41,8 persen responden menjawab dianjurkan, 3 orang atau 2.0 persen menjawab tidak boleh dan 21 orang atau 13,7 persen responden menjawab tidak tahu.

Adapun tentang bagaimana hukum menabung di bank konvensional maka 68 responden atau 44,4 persen responden menjawab boleh menabung di bank konvensional, 34 orang atau 22,2 persen resonden menjawab tidak boleh, dan 51 orang atau 33,3 persen responden menjawab tidak tahu.

Adapun mengenai setujukah responden bahwa menabung di bank konvensional termasuk akad ribawi?. 23 orang atau 15,0 persen responden menjawab sangat setuju, 50 orang atau 32,7 persen responden menjawab setuju, 45 orang atau 29,4 persen responden menjawab cukup setuju, 23 orang atau 15,0 persen responden menjawab tidak setuju, 1 orang atau 0,7 persen responden menjawab sangat tidak setuju dan 11 orang atau 7,2 persen responden tidak menjawab.

Dari segi pengetahuan responden tentang hukum menabung di bank konvensional adalah akad ribawi, maka 17 orang atau 11,1 persen responden menjawab sangat tahu, 47 orang atau 30,7 persen responden menjawab tahu, 55 orang atau 35,9 persen responden menjawab cukup tahu, 22 orang atau 14,4 persen responden menjawab tidak tahu, 1 orang atau 0,7 persen menjawab sangat tidak tahu dan 11 orang atau 7,8 persen responden tidak menjawab.

\section{Literasi Keuangan Syariah Masyarakat Kota Tangerang}

Berdasarkan hasil survei di 13 kecamatan di Kota Tangerang dapat diketahui bahwa tingkat pengetahuan masyarakat kota Tangerang mengenai keuangan syariah adalah sebagai berikut, 1 orang atau 0,7 persen responden menjawab sangat tahu, 22 orang atau 14,4 persen responden menjawab tahu, 84 orang atau 54,4 persen responden menjawab cukup tahu, 42 orang atau 27,5 persen responden menjawab tidak tahu dan 3 orang atau 2.0 persen responden menjawab sangat tidak tahu.

Adapun tentang keyakinan masyarakat tentang kesyariahan bank syariah maka berdasarkan hasil survei di 13 kecamatan 
143 AL-URBAN: Jurnal Ekonomi Syariah dan Filantropi Islam

Vol. 2, No. 2, Desember 2018

http://journal.uhamka.ac.id/index.php/al-urban

p-ISSN: 2580-3360 e-ISSN: 2581-2874

DOI: $10.22236 /$ alurban_vol2/is2pp135-145

Hal 135-145

di kota Tangerang dapat diketahui bahwa 7

syariah maka berdasarkan hasil survei dapat orang atau 4,6 persen responden menjawab sangat yakin, 56 orang atau 36,6 persen responden menjawab yakin, 65 orang atau 42,5 persen responden menjawab cukup yakin, 24 orang atau 15,7 pesen responden menjawab tidak yakin dan 1 orang atau 0,7 persen menjawab sangat tidak yakin.

Sedangkan mengenai keterampilan diketahui bahwa 3 orang atau 2.0 persen responden menjawab sangat terampil, 39 orang atau 25,5 persen responden menjawab terampil, 61 orang atau 39,9 responden menjawab cukup terampil, 42 orang atau 27,5 persen responden menjawab tidak terampil dan 6 orang atau 3,9 persen masyarakat dalam menggunakan keuangan

\section{Hubungan Persepsi Masyarakat Kota Tangerang Dengan Tingkat Literasi \\ Keuangan Syariah}

Tabel 3

Korelasi Kendall Tau

Correlations

\begin{tabular}{|lll|r|r|}
\hline & & \multicolumn{1}{|c|}{ Persepsi } & \multicolumn{1}{|c|}{ Literasi } \\
\hline Kendall's tau_b & Persepsi & Correlation & 1.000 & .290 \\
& & & .000 \\
& Coefficient & 142 & 139 \\
& Sig. (2-tailed) & $.290^{*}$ & 1.000 \\
& N & .000 & \\
\cline { 2 - 4 } & Correlation & 139 & 150 \\
& Coefficient & & \\
& Sig. (2-tailed) & N & \\
& &
\end{tabular}

**. Correlation is significant at the 0.01 level (2-tailed).

Kuatnya korelasi diukur dengan membandingkan $r$ hitung dengan $r$ tabel. Apabila nilai $r$ hitung lebih besar dari nilai $r$ tabel yaitu 0,148 (taraf signifikansi 1 persen dengan sampel 153) maka hal tersebut berarti korelasi tersebut kuat.

Berdasarkan hasil analisis diatas, korelasi antara Persepsi Masyarakat tentang hukum syariah menabung di bank terhadap tingkat literasi keuangan syariah adalah 0,290 lebih besar dari 0,148, hal tersebut berarti terdapat hubungan yang kuat antara persepsi masyarakat kota Tangerang tentang hukum menabung di bank dengan tingkat literasi keuangan syariah.

\section{SIMPULAN}

Hasil dari peneltian yang dilakukan di Kota Tangerang tentang persepsi mereka tentang hukum syariah menabung di bank, dapat diambil kesimpulan bahwa persepsi masyarakat Kota Tangerang tentang hukum menabung di bank syariah didominasi dengan dianjurkan, yaitu sebanyak 64 orang atau 41.8 persen. Adapun tentang hukum menabung di bank konvensional kebanyakan masyarakat kota Tangerang menjawab bahwa menabung di bank konvensional adalah boleh, yaitu 68 orang atau 44,4 persen. Tingkat literasi keuangan syariah mayarakat Kota Tangerang masih 
Atep Hendang Waluya 144

rendah, Dalam hal pengetahuan masyarakat tentang keuangan syariah, mayoritascukup tahu tentang keuangan syariah, yaitu 84 orang atau 54,9 persen. Tentang kesyariahan bank syariah mayoritas masyarakat kota Tangerang cukup yakin dengan kesyariahan bank syariah, yaitu 65 orang atau 42,5 persen dan yang paling rendah adalah indikator keterampilan mereka dalam menggunakan layanan keuangan syariah, yaitu 61 orang atau 39,9 persen cukup terampil.

\section{REFERENSI}

Al Munajjid, Muhammad bin Shalih. (2017). Ma Hukmu Al 'Ida Fi Al Banuk Al Ribawiyyah Duna Faidah. Di akses pada 2 Oktober 2018 dari https://islamqa.info/ $\underline{\operatorname{ar} / 226729}$

Badan Pusat Statistik. (2010). Jumlah dan Distribusi Penduduk. Diakses pada 1 Maret 2017 dari http:// sp2010.bps.go.id

Badan Pusat Statistik. 2010. Provinsi Banten Penduduk Menurut Kelompok Umur Dan Agama Yang Dianut. Diakses pada 1 Maret 2017 dari http://sp2010.bps.go.id/

Badan Pusat Statistik. (2010). Kota Tangerang Penduduk Menurut

Wilayah dan Agama Yang Dianut. Diakses pada I Juli 2017 dari http://sp2010.bps.go.id/

Herdianti, Ika Fitri dan Satria Utama. (2017). Analisis Tingkat Literasi Keuangan Syariah Mahasiswa
Serta Pengaruhnya

Terhadap Minat Mahasiswa Menjadi Nasabah Pada Lembaga Keuangan Syariah. Di akses dari www.repository.umya.ac.id

Islam Web.(1996). Hukmul 'Ida Fi Banuk Ribawi li 'Adami Wujudi Bank Islami. Di akses dari http://fatwa. islamweb.net/fatwa/pada 1 Maret 2017

Mendari, Anastasia Sri dan Fransiska Soejono. (2018). Literasi Keuangan Dosen-Dosen Diperguruan Tinggidi Palembang. Benefit Jurnal Manajemen dan Bisnis. Vol 3 No 1

Otoritas Jasa Keuangan. (2018). Siaran Pers: Market Share Keuangan Syariah Capai 8 Persen. Di akses dari https://www.ojk.go.id/id/, pada 3 Oktober 2018

Otoritas Jasa Keuangan. (2017). Data Statistik Perbankan Syariah Desember 2016. Diakses dari http://www.ojk.go.id/id pada 1 Maret 2017

Otoritas Jasa Keuangan. (2017). Data Statistik Perbankan Indonesia Desember 2016. Diakses dari http://www.ojk.go.id/id pada 1 Maret 2017

Otoritas Jasa Keuangan. (2017). Siaran Pers: OJK: Indeks Literasi dan Inklusi Keuangan Meningkat. Diakses dari www.ojk.go.id/idpada 1 Maret 2017

Prasetyo, Luhur. 2012. Perkembangan 
145 AL-URBAN: Jurnal Ekonomi Syariah dan Filantropi Islam Vol. 2, No. 2, Desember 2018

http://journal.uhamka.ac.id/index.php/al-urban p-ISSN: 2580-3360 e-ISSN: 2581-2874

DOI: $10.22236 /$ alurban_vol2/is2pp135-145

Hal 135-145

Bank Syariah Pasca UU 21 tahun

2018. Jurnal Al Tahrir. Vol 12 no 1

Rahmawaty, Anita. (2014). Pengaruh

Persepsi Tentang Bank Syariah

Terhadap Minat Menggunakan

Produk Di Bank Syariah

Semarang. Jurnal Addin. Vol 8

no1

Sevilla, Consuelo G. et. al. (2007).

Research Methods. Quezon City:

Rex Printing Company

Sugiyono. 2004. Metode Penelitian Bisnis.

Bandung: Alfabeta

Waluya, Atep Hendang. (2017). The Essence

Of Al wadiah Al Mashrifiyyah.

Jurnal Lariba. Vol 2 No 2 